Minkó-Miskovics Mariann - Szabó Csaba

\title{
A polgári és a haditechnikai felhasználású eszközök szabályozásának hazai és nemzetközi kérdései
}

\author{
Domestic and international issues in the regulation \\ of civil and military equipment
}

\begin{abstract}
Absztrakt
A polgári és a haditechnikai felhasználású eszközök jogi szabályozása marginális, nem különösebb jelentőséggel rendelkező területnek tünhet. Ez a szabályozás ugyanakkor szektorálisan jelentősnek tekinthető, különösen az egyes szektorokon belül, így a polgári lőfegyverekkel és tartozékaikkal, illetve a haditechnikai termékekkel foglalkozó szervezetek számára. A szabályozás ugyanakkor egy átfogó, több európai uniós és magyar jogszabályból álló, viszonylag szük körü jogalkalmazói gyakorlattal rendelkező rendelkezéshalmazt alkot, amelynek részletes magyar vizsgálatára eddig még egyáltalán nem került sor.
\end{abstract}

Kulcsszavak: polgári lőfegyverek, haditechnika, jogalkotás, jogértelmezés, lőfegyverek

\begin{abstract}
The legal regulation of civil and military equipment is marginal, may seem to be an area with no particular importance. However, this regulation can be considered sector-significant, especially within individual sectors, such as organizations dealing with civilian firearms, their accessories and military equipment. At the same time, the regulation forms a comprehensive set of provisions consisting of several European Union and Hungarian legal acts with a relatively narrow legal application practice, which so far has not yet been examined in detail in Hungary.
\end{abstract}

Keywords: civilian firearms, military technology, legislation, legal interpretation, firearms 


\section{Jogszabályi háttér}

A vonatkozó - haditechnikai termékkel és lőfegyverrel kapcsolatos - rendelkezések alapvetően öt magyar jogszabályban jelennek meg, amelyek két területre összpontosulnak. A szabályozás egyik részét a haditechnikai jogszabályok, így a haditechnikai termékek gyártásának és a haditechnikai szolgáltatások nyújtásának engedélyezéséről szóló 2005. évi CIX. törvény (a továbbiakban: Httv.), a haditechnikai tevékenység engedélyezésének és a vállalkozások tanúsításának részletes szabályairól szóló 156/2017. (VI. 16.) Korm. rendelet (a továbbiakban: Htkr.) és a haditechnikai termékek jelöléséröl, valamint a haditechnikai termékek és szolgáltatások nyilvántartásáról szóló 32/2007. (III. 19.) GKM rendelet (a továbbiakban Htr.) alkotja. A szabályozás másik része pedig a lőfegyverekkel kapcsolatos jogszabályokban, tehát a lőfegyverekről és lőszerekről szóló 2004. évi XXIV. törvényben (a továbbiakban: Lftv.), a fegyverekről és löszerekről szóló 253/2004. (VIII. 31.) Korm. rendeletben (a továbbiakban: Lfkr.) található. A magyar szabályozás alapját az említett nemzeti jogszabályok mellett a haditechnikai termékek, a kettős felhasználású termékek és a lőfegyverek esetében több európai uniós jogi aktus alkotja, így a védelmi vonatkozású termékek transzferéről szóló parlamenti és tanácsi irányelv (a továbbiakban: 2009/43/EK irányelv) ${ }^{1}$ és a kettős felhasználású termékekről szóló tanácsi rendelet (a továbbiakban: 428/2009/EK rendelet) ${ }^{2}$, illetve a fegyverekre vonatkozó tanácsi irányelv (a továbbiakban: 91/477/EGK irányelv). ${ }^{3}$

Ezek a jogszabályok foglalják keretbe a polgári és haditechnikai eszközökre, így különösen a fegyverekre vonatkozó szabályozást, figyelemmel ezek európai uniós megfelelőire is. Az említett jogszabályok - ideértve az európai uniós jogszabályokat is - néhány esetben átfedéseket tartalmaznak és egyes esetekben nem teljes mértékben követhetők, melynek eredményeként a jogalkalmazó sem tudott megfelelően egységes gyakorlatot kialakítani.

\section{Haditechnikai termék kontra kettős felhasználású termék}

A szabályozás alapját a haditechnikai termék és a lőfegyver fogalmai alkotják, amelyek - tekintettel a tárgyi hatály hasonlóságára - egyes esetekben meg-

1 Az Európai Parlament és a Tanács 2009/43/EK irányelve (2009. május 6.) a védelmi vonatkozású termékek Közösségen belüli transzferére vonatkozó feltételek egyszerüsítéséröl.

2 A Tanács 428/2009/EK rendelete (2009. május 5.) a kettős felhasználású termékek kivitelére, transzferjére, brókertevékenységére és tranzitjára vonatkozó közösségi ellenőrzési rendszer kialakításáról.

3 A Tanács irányelve (1991. június 18.) a fegyverek megszerzésének és tartásának ellenőrzéséről. 
egyeznek egymással. Megjegyzendő emellett, hogy a haditechnikai termék és a lőfegyver fogalmai kiemelt szereppel rendelkeznek a kettős felhasználású termékek tekintetében is, amelyek esetében a felhasználás típusaként egyaránt megjelenik a haditechnikai és a polgári felhasználás.

\section{Fogalmi háttér: haditechnikai termék, kettős felhasználású termék, vagy löfegyver?}

A haditechnikai termék fogalmát a Httv. utaló formában határozza meg és rögzíti, hogy haditechnikai terméknek ${ }^{4}$ minősül a Htkr.-ben meghatározott termék. ${ }^{5} \mathrm{~A}$ haditechnikai termék ugyanakkor - figyelemmel a haditechnikai termék külkereskedelmének fogalmára - nem tekinthető egyenlőnek a haditechnikai eszközzel. ${ }^{6} \mathrm{~A}$ Htkr.-ben foglaltak szerint haditechnikai eszköz a Htkr. 1. mellékletében meghatározott termék. ${ }^{7} \mathrm{~A}$ Htr. nem határozza meg a két másik jogszabály által említett fogalmakat, viszont a haditechnikai terméket a Htkr.-ben foglalt haditechnikai termékként és szolgáltatásként értelmezi. ${ }^{8}$ Ennek alapján a jogalkotó a törvényi termék fogalmat a kormányrendeletben eszközként és termékként értelmezi, míg a rendeletben kizárólag termék és szolgáltatás szerepel, így viszont a termék egyszerre tekinthető eszköznek és szolgáltatásnak is. ${ }^{9}$ Megjegyzendő, hogy ezen eltérés felmerülésének indoka egy korábbi jogszabály, a Htkr.-rel hatályon kívül helyezett, a haditechnikai eszközök és szolgáltatások kivitelének, behozatalának, transzferjének és tranzitjának engedélyezéséről, valamint

4 Megjegyzendő, hogy a haditechnikai termék jelenlegi fogalma viszonylag frissnek tekinthető. Egy 2019-ben elfogadott jogszabály módosította azt: az eredeti fogalom szerint ,haditechnikai terméknek vagy szolgáltatásnak minösül a védelem terén alapvetö biztonsági érdeket érintö, kifejezetten katonai, nemzetbiztonsági, rendvédelmi és rendészeti célokra alkalmas, az Európai Unió közös katonai listáján található, illetve nemzeti érdekböl ide sorolt termék vagy szolgáltatás". Egyes törvények ipar- és kereskedelemszabályozási szempontból történő, valamint jogharmonizációs célú módosításáról a 2019. évi LXXXIII. törvény 16. § és indokolása rendelkezik. A jogszabály indokolása szerint azért szükséges a módosítás, mivel „A haditechnikai termék, szolgáltatás hatályos fogalommeghatározása hibás jogértelmezésre ad okot, ezért szükséges módositani. Világossá kell tenni, hogy azt a terméket kell haditechnikaként kezelni, ami rajta van az ellenörzési listán." (URL1)

5 2005. évi CIX. törvény $1 . \S \mathrm{c}$ ) pont.

6 2005. évi CIX. törvény $1 . \S \mathrm{j}$ ) pont.

7 156/2016. (VI. 16.) Korm. rendelet 2. § 10. pont.

8 32/2007. (III. 19.) GKM rendelet 1. § (1) bekezdés.

9 Megjegyzendő, hogy a termék fogalmát több jogszabály is meghatározza, így a Polgári Törvénykönyvről szóló 2013. évi V. törvény, a termékek piacfelügyeletéről szóló 2012. évi LXXXVIII. törvény, a szolgáltatási tevékenység megkezdésének és folytatásának általános szabályairól szóló 2009. évi LXXVI. törvény, a kereskedelemről szóló 2005. évi CLXIV. törvény, továbbá a fogyasztóvédelemről szóló 1997. évi CLV. törvény, amelyek nem tekinthetők egyik, jelen tanulmány vizsgálódásainak tárgyát képező jogszabályok hattárjogszabályainak sem, függetlenül attól, hogy egyes esetekben a termék fogalmának meghatározása alkalmazható lenne. Ezzel szemben az eszköz fogalmának jogszabályi meghatározására egyáltalán nem került sor. 
a vállalkozások tanúsításáról szóló 160/2011. (VIII. 18.) Korm. rendelet (a továbbiakban: Htekr.). A Htekr. fogalommeghatározása szerint megfeleltethető az eszköz fogalma a termék fogalmával. Az említett rendelkezés szerint a haditechnikai eszköz a Htekr. mellékletében szereplö, a védelem terén alapvető biztonsági érdekeket érintő, kifejezetten katonai, nemzetbiztonsági, rendvédelmi és rendészeti célokra alkalmas, az Európai Unió közös katonai listáján ${ }^{10}$ található, illetve nemzeti biztonsági érdekből ide sorolt termék. ${ }^{11}$ Ennek alapján tehát a haditechnikai termék egyszerre tekinthetö haditechnikai eszköznek és szolgáltatásnak, de csak meghatározott esetekben és csak meghatározott jogszabályok alapján. A helyzetet ráadásul tovább nehezíti, hogy gyakorlatban sem került sor a termék és az eszköz fogalmainak értelmezésére, elhatárolására, ideértve a haditechnikai termék és a haditechnikai eszköz fogalmait is.

A haditechnikai termék - haditechnikai eszköz fogalmainak egymáshoz való viszonyát az 1 . számú ábra jeleníti meg.

1. számú ábra: A termék és az eszköz fogalmainak kapcsolata az egyes jogszabályokban

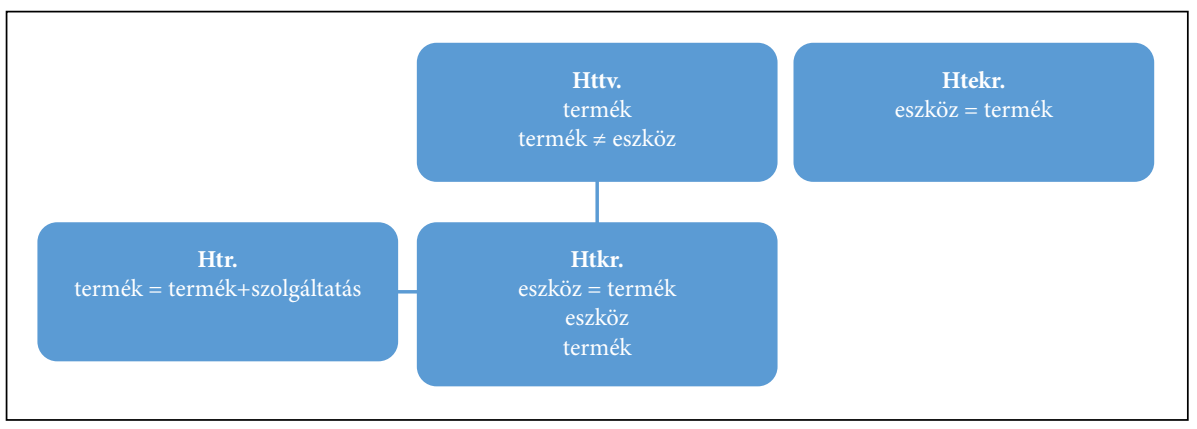

Forrás: Az ábra a jogszabályok alapján került összeállításra.

A haditechnikai termék mellett érdemes megvizsgálni a kettős felhasználású termék fogalmát is, amely azon termékek körét tartalmazza, amelyek nem kizárólag haditechnikai célból kerülhetnek felhasználásra, hanem polgári (például sport vagy vadászat) felhasználásúak is lehetnek. A magyar jogban nem került sor a kettős felhasználású termék fogalmának meghatározására, a vonatkozó jogszabály - a kettős felhasználású termékek külkereskedelmi forgalmának engedélyezéséröl szóló 13/2011. (II. 22.) Korm. rendelet (a továbbiakban:

10 A Tanács az Európai Unió közös katonai listája a Tanács által 2017. március 6-án elfogadva (a katonai technológia és felszerelések kivitelének ellenőrzésére vonatkozó közös szabályok meghatározásáról szóló 2008/944/KKBP tanácsi közös álláspont által szabályozott eszközök).

11 160/2011. (VIII. 18.) Korm. rendelet 1. § 8. pont. 
Kfkr.) - egy utaló rendelkezést tartalmaz egy európai uniós tanácsi irányelvre. ${ }^{12} \mathrm{Az}$ említett irányelv szerint kettős felhasználású terméknek azok a termékek minősülnek, amelyek polgári és katonai célokra egyaránt felhasználhatók, illetve amelyek egyaránt felhasználhatók nem robbantási célokra és nukleáris fegyverek vagy más nukleáris robbanószerkezetek előállításához történő, bármilyen formájú hozzájárulás céljára. ${ }^{13} \mathrm{~A}$ kettős felhasználású termékek vonatkozásában kiemelendő, hogy az egyik oldalon a katonai-haditechnikai termékek jellennek meg, míg a másik oldalon a polgári (tehát vadászati vagy sportcélú) felhasználású termékek találhatók, így különösen a lőfegyverek és a légfegyverek. A vonatkozó jogszabály (a továbbiakban: Lftv.) szerint fegyvernek minősül a lőfegyver, a gáz- és riasztófegyver, a légfegyver, a festéklövő fegyver, a muzeális fegyver, valamint a színházi fegyver. ${ }^{14} \mathrm{~A}$ fogalmi eltéréseket megvizsgálva megállapítható, hogy nem került sor egységes fogalmak alkalmazására, az egyes jogszabályok fogalomhasználata egyes esetekben eltér egymástól. ${ }^{15}$ Ezt erősíti meg a - rendkívül kevés - rendelkezésre álló bírósági határozat is. Az egyik ilyen bírósági határozatban foglaltak szerint ugyanis - hivatkozva egy szakértői véleményre - sok olyan eszköz is haditechnikai eszköznek minősül a jogszabályok alapján, amely ma már gyerekjátékként is felhasználható, ugyanakkor a bíróság minden esetben a jogszabályokban foglalt rendelkezésekhez kötött, függetlenül attól, hogy az adott jogszabályi rendelkezés már túlhaladottnak tekinthető vagy sem. ${ }^{16}$ Egy másik bírósági határozatban rögzítésre került, hogy az egyes eszközök megfelelő kategóriákba (értsd: haditechnikai vagy nem haditechnikai eszköz) besorolása a szakértői vizsgálat során a szakértőknek és az eszközökkel foglalkozó Nemzetbiztonsági Szakszolgálat vizsgálatokat végző alkalmazottainak is nehézséget okozott. ${ }^{17}$ A jogalkalmazó egy másik bírósági határozatban rögzítette továbbá, hogy a hadipuska-töltény nem használható polgári célra, tehát nem minősül a haditechnikai jogszabályokban meghatározott privilegizált esetként felsorolt polgári lőfegyverekhez tartozó lőszernek. Ebben az esetben ugyanis lőfegyverrel visszaélés büncselekménye

12 13/2011. (II. 22.) Korm. rendelet 1. § (1) bekezdés.

13 A Tanács 428/2009/EK rendelete (2009. május 5.) a kettős felhasználású termékek kivitelére, transzferjére, brókertevékenységére és tranzitjára vonatkozó közösségi ellenőrzési rendszer kialakításáról 2. cikk 1. pont.

14 A lőfegyverekről és lőszerekről szóló 2004. évi XXIV. törvény 2. § 38. pont.

15 A fogalmi eltérések-átfedések egyértelműen megjelennek a büntetőjogban is, figyelemmel a jelenleg hatályos Büntető Törvénykönyvben egymástól elkülönítve megjelenő - kerettényállás formájú büncselekményekre, így a lőfegyverrel vagy lőszerrel visszaélés, a haditechnikai termékkel vagy szolgáltatással visszaélés, illetve a kettős felhasználású termékkel visszaélés büncselekményeire. A Büntető Törvénykönyvről szóló 2012. évi C. törvény 325. §, 329-330. §.

16 Csongrád Megyei Bíróság B.1059/2007.30.

17 Fővárosi Bíróság B.255/2009.82. 
merült fel hadipuska-töltény szentimentális okokból történő megtartása miatt. A jogesetből mindenképp kiemelendő a jogalkalmazó azon értelmezése, amely szerint kézilőfegyver alatt nemcsak olyan lőfegyver értendő, amelyet polgári személy engedéllyel megszerezhet és tarthat, függetlenül attól, hogy a kézilöfegyver fogalma nem került meghatározásra. ${ }^{18}$ Ez utóbbi határozat azért tekinthető jelentősnek, mert a jogalkalmazó egyértelmüen megállapította, hogy egyes olyan eszközök, amelyek a Htkr.-ben haditechnikai eszközként kerülnek megjelölésre, nem minden esetben tekinthetők ténylegesen haditechnikai eszköznek, a felhasználás célja és módja befolyásolja az eszköz minősülését. Ebben az esetben mégis a jogalkotónak a jogszabály megalkotásával kapcsolatos célját is vizsgálni kell, hiszen - amennyiben a felhasználás célja nem tekinthető elégségesnek az eszköz meghatározott csoportba történő besorolásához - ennek alapján egyértelmüen eldönthető, hogy ténylegesen milyen cél érdekében került sor a szabályozás megalkotására. Ez pedig kifejezetten rögzítésre került az Alaptörvényben a jogértelmezés vonatkozásában: jogszabályok szövegének értelmezése elsősorban azok céljával összhangban történik és az értelmezés során feltételezni kell, hogy a jogszabályok a józan észnek és a közjónak megfelelő, gazdaságos célt szolgálnak. ${ }^{19}$ Az Alaptörvény ezen rendelkezését tekintve pedig megállapítható, hogy az Httv. és a kapcsolódó jogszabályai eltérő célra irányulnak, mint az Lftv. és kapcsolódó jogszabályai, emellett a gazdaságosság kizárólag akkor érvényesülhet megfelelően, ha az értelmezés során elkülönítésre kerül a két szabályozási terület, ideértve az egyes eljárásjogi szabályokat is. Tehát adott esetben még a jogszabálymódosítás is elkerülhető lenne megfelelö, Alaptörvény-konform értelmezés bíróságok - és ennek alapján az eljáró hatóságok - általi alkalmazásával.

Kiemelendő emellett az a - szintén a büntetőjog területén - hozott határozat, amely segít értelmezni egy hasonló esetet is. Ebben kimondásra került, hogy az európai uniós szabályozással szemben a magyar jog nem ír elő müszaki paramétereket a titkosszolgálati eszközök tekintetében, de alkalmatlanságuk esetén ezek az eszközök nem lehetnek az elkövetés tárgyai a haditechnikai termékkel visszaélés büntettének. ${ }^{20}$ Ezen határozat alapján, amennyiben egy eszköz nem alkalmas haditechnikai célokra, nem tekinthető haditechnikai terméknek vagy eszköznek, helyette inkább polgári felhasználású eszköznek minősül. A határozatokat vizsgálva megállapítható, hogy a joggyakorlat minden esetben egyértelmüen a jogszabályokban foglaltakat követi, még abban az esetben is, ha az

18 Fővárosi Ítélőtábla Bhar.280/2018/6.

19 Alaptörvény 28. cikk.

20 Fővárosi Ítélőtábla 4.Bf.15/2013. I. 
adott eszköz besorolása nem állapítható meg egyértelmüen, ideértve a müszaki paraméterek megállapításának hiányát is.

\section{A vonatkozó európai uniós szabályozás: az ellentétek feloldása?}

A 2009/43/EK irányelv preambulumában a jogalkotó rögzíti, hogy az irányelv rendelkezései nem érintik a 91/477/EGK irányelv rendelkezéseit. ${ }^{21}$ A 2009/43/EK irányelv vizsgálata során megállapításra került, hogy több átfedés és következetlenség áll fenn az 2009/43/EK irányelv és a tüzfegyverekre vonatkozó rendelet, illetve a 91/477/EGK irányelv vonatkozásában. ${ }^{22}$ Ez a gyakorlatban azt jelenti, hogy a 91/477/EGK irányelv nem vonatkozik a fegyvereknek és lőszereknek a fegyveres erők, a rendőrség - tehát a katonai és rendészeti szervek által a nemzeti jogszabályok szerint történő megszerzésére és tartására, illetve nem alkalmazandó a hadifegyverek és lőszerek kereskedelmi szállítására. ${ }^{23}$

Az Európai Unió Bírósága - hasonlóan a magyar bíróságokhoz - gyakorlatilag alig foglalkozott a haditechnika polgári felhasználás kérdéskörével. Az egyetlen kapcsolódó ítélet szerint a 91/477/EGK irányelv olyan intézkedésnek tekinthető, amely az áruk - azaz a polgári felhasználásra szánt tüzfegyverek szabad mozgása tekintetében a tagállamok törvényi, rendeleti és közigazgatási rendelkezései közelítésének biztosítására irányul. Emellett a 91/477/EGK irányelv olyan tüzfegyver-kategóriákról rendelkezik, amelyeknek a magánszemélyek általi megszerzése és tartása tilos, illetve engedélyhez vagy bejelentéshez kötött. ${ }^{24} \mathrm{~A}$ fentiek alapján megállapítható, hogy az európai uniós szabályozás kisebb mértékben egyértelmübbnek és pontosabbnak tekinthető, mint a magyar jogszabályok, ugyanakkor ebben az esetben is megjelennek átfedések és nem tekinthető teljes mértékben kielégítőnek a szabályozás.

\section{A magyar jogszabályi átfedések: az ML1 lista kérdésköre}

A fogalmi átfedések mellett további nehézséget okoz, hogy egyes kettős felhasználású termékek (például a polgári felhasználású golyós vagy sörétes löfegyverek) esetében a gyakorlat inkább a haditechnikai cél irányába mozdult el, gyakorlatilag figyelmen kívül hagyva a nem csak katonai célú felhasználást.

21 2009/43/EK irányelv preambulum (15) bekezdés.

22 A Bizottság jelentése az Európai Parlamentnek és a Tanácsnak: A védelmi vonatkozású termékek Közösségen belüli transzferjére vonatkozó feltételek egyszerüsítéséről szóló, 2009. május 6-i 2009/43/ EK európai parlamenti és tanácsi irányelv értékelése, COM (2016) 760 final.

23 91/477/EGK irányelv 2. cikk (2) bekezdés.

24 C-482/17. sz. Cseh Köztársaság kontra Európai Parlament és az Európai Unió Tanácsa 48. és 54. pontok. 
Ezen termékek - többek között - a Htkr. 1. mellékletébe, az engedélyköteles haditechnikai eszközök és szolgáltatások jegyzékének I. fejezetébe (a továbbiakban: ML1) tartozó termékek, illetve eszközök. Az ML1 címe szerint ebbe a körbe a - müszakilag pontosan meghatározott - , huzagolatlan csövü fegyverek 20 mm-nél kisebb kaliberrel, más kézifegyverek és automata fegyverek 12,7 mm (0,50 hüvelyk/inch) vagy kisebb kaliberrel és tartozékok a következök szerint, és a kifejezetten azokhoz tervezett részegységek" tartoznak, így különösen a puskák és vegyescsövü fegyverek, kézifegyverek, géppuskák, géppisztolyok és sorozatvetők. Ebbe a körbe tartoznak még a huzagolatlan csövü fegyverek meghatározott típusai (például a kifejezetten katonai célokra tervezett huzagolatlan csövü fegyverek vagy a teljesen automata típushoz tartozó fegyverek), a hüvely nélküli lőszerrel müködő fegyverek és az ilyen típusú fegyverekhez tervezett tartozékok. ${ }^{25}$ Észrevétel, hogy az ML1 nem vonatkozik meghatározott típusú fegyverekre, mint például a nem teljesen automata fegyverekre, a muzeális fegyverekre, a hatástalanított tüzfegyverekre és - kiemelendő módon - a vadászati és sport célra használt, nem kifejezetten katonai célra tervezett vagy automata tüzelésü rendszerü huzagolatlan csövü (közismertebb nevén sörétes) ${ }^{26}$ fegyverekre. ${ }^{27}$

Az ML1 vonatkozásában az értelmezési nehézségeket okozó kérdések az egyes területeket szabályozó jogszabályok által alkalmazott fegyverfogalmakban keresendő. A Htkr.-ben foglaltak szerint ugyanis minden, az ML1-ben meghatározott fegyverre és tartozékra a Httv. és a Htkr. vonatkozik, ugyanakkor egyes ott meghatározott fegyverek - így különösen egyes puskák és vegyescsövü fegyverek, a félautomata és pumpás müködtetésủ típushoz tartozó, vadászatra vagy sport célra használt sörétes, nem kifejezetten katonai célra tervezett fegyverek, illetve a hüvely nélküli lőszerrel müködő fegyverek - kettős felhasználásúnak tekinthetők, és a Lftv. hatálya alá is tartoznak. Ugyanakkor ennek alapján a polgári felhasználású huzagolt csövü (közismertebb elnevezést használva a golyós) fegyverek - mivel nem kerültek kivételként meghatározásra az ML1-ben - kifejezetten haditechnikai terméknek tekinthetők, és a velük kapcsolatosan végzett tevékenység hadiipari tevékenységnek minősül ${ }^{28}$. Megjegyzendő, hogy ebben az esetben is fogalmi különbségek jelennek meg a Httv. és a Htkr. között, hiszen a törvény a „hadiipari tevékenység” kifejezést alkalmazza, amelybe kizárólag a gyártás és a szolgáltatásnyújtás tartozik; ezzel szemben a kormányrendelet

25 156/2017. (VI. 16.) Korm. rendelet I. melléklet I. fejezet.

26 A huzagolatlan csövű fegyver a gyakorlatban nem más, mint a sörétes fegyver (Fábián, 2015).

27 156/2017. (VI. 16.) Korm. rendelet I. melléklet I. fejezet a)-c) pontokhoz füzött megjegyzések.

28 A hadiipari tevékenység a Httv. szerint haditechnikai termék gyártását vagy haditechnikai szolgáltatás nyújtását foglalja magába. 2005. évi CIX. törvény 1 . § b) pont. A haditechnikai termék gyártásának és a haditechnikai szolgáltatás nyújtásának fogalmát a Httv. 1. § d)-e) pontjai tartalmazzák. 
végig a „haditechnikai tevékenység” kifejezést használja, amelyet szélesebb körben alkalmaz; a gyártás és a szolgáltatásnyújtás mellett ebbe a körbe tartozik még a jogszabály szerint a külkereskedelem is. ${ }^{29}$ Ezen fogalmi és tartalmi eltérés indoka vélelmezhetően a Httv. korábbi megalkotása lehet. Ez azért okoz nehézségeket, mert a polgári felhasználású golyós fegyverek esetében is meghatározott típusú haditechnikai engedély megléte szükséges, különös figyelemmel arra, hogy az ML1 nem tartalmaz az ilyen típusú fegyverekre kivételi köröket.

\section{Eljárásjogi kérdések}

Az eddig szemléltetettek alapján megállapítható, hogy egyszerre két jogszabály is rendelkezik több olyan fegyvertípusról, amelyek kettős felhasználásúnak tekinthetők. A kapcsolódó eljárásjogi kérdések tekintetében már lényegesen nehezebb elkülöníteni azokat a hatáskörrel rendelkező hatóságokat, amelyek ezekhez a fegyverekhez kapcsolódó egyes engedélyezési feladatokat ellátják, tekintettel arra, hogy az egyes hatóságok hatásköre esetében több jogszabály is alkalmazandó.

\section{Hatályra vonatkozó rendelkezések}

A hatállyal kapcsolatos nehézséget az okozza, hogy az Lftv. kifejezetten rögzíti, hogy rendelkezései nem alkalmazandók - többek között - a haditechnikai termékek gyártásának és a haditechnikai szolgáltatások nyújtásának engedélyezéséről szóló törvényben haditechnikai termékként meghatározott eszközök tekintetében a hadiipari tevékenység végzéséhez szükséges engedély alapján végzett tevékenységek hatósági engedélyezésére. ${ }^{30}$ Ezzel szemben a Htkr. egyik mellékletében meghatározza az engedélyköteles haditechnikai termékek körét, amelyek esetében haditechnikai engedély megléte szükséges, azonban itt kivételeket is szerepeltet, így különösen az ML1 megjegyzéseiben felsorolt eszközökre. A Htkr. emellett csak azt mondja ki, hogy az ML1 nem vonatkozik a megjegyzésekben meghatározott eszközökre, azt nem rögzíti kifejezetten, hogy azok más hatósági engedélyezés körébe tartoznának. Az ellentmondás elméletben feloldhatónak tekinthető, hiszen a jogalkotásról szóló törvényben foglaltak szerint az azonos vagy hasonló életviszonyokat azonos vagy hasonló módon kell szabályozni, amely nem lehet indokolatlanul párhuzamos vagy többszin-

29 2005. évi CIX. törvény 1. § b) pont és 156/2017. (VI. 16.) Korm. rendelet 2. § 12. pont.

30 2004. évi XXIV. törvény 1 . $\S(2)$ bekezdés b) pont. 
tü $^{31}$, tehát a Lftv.-ben foglalt szabályozás - a lőfegyvertartási célok figyelembevételével - magasabb szintü törvényi szabályozás, mint a Htkr. mellékletében, mint alacsonyabb szintü jogszabályban foglalt rendelkezések. ${ }^{32}$

\section{Engedélyezési feladatok: melyik hatóság rendelkezik hatáskörrel?}

A haditechnikai engedélyezési, illetve a kettős felhasználású termékekkel kapcsolatos feladatokat Budapest Főváros Kormányhivatalának Kereskedelmi, Haditechnikai, Exportellenőrzési és Nemesfémhitelesítési Főosztálya (a továbbiakban: BFKH) látja el 2017. január 1-jétöl. ${ }^{33}$ A haditechnikai engedélyeket a BFKH meghatározott célokra adja ki, így létezik tevékenységi engedély (gyártás, szolgáltatásnyújtás, külkereskedelemmel kapcsolatos előkészítő tevékenység, így piackutatás, ajánlattétel, előkészítő tárgyalások végzése ${ }^{34}$ ), tárgyalási engedély (kivitel, újrakivitel, harmadik ország részére történő szolgáltatásnyújtás ${ }^{35}$ ), forgalmi engedély (kivitel, újrakivitel, behozatal, transzfer, szolgáltatásnyújtás ${ }^{36}$ ), brókerengedély ${ }^{37}$, tranzitengedély ${ }^{38}$. A kettős felhasználású termékek esetében - hasonlóan a haditechnikai termékek engedélyezéséhez - létezik exportengedély ${ }^{39}$, transzferengedély ${ }^{40}$, brókerügyleti engedély ${ }^{41}$ és tranzit engedély ${ }^{42}$. A lőfegyverekkel kapcsolatos engedélyezési feladatok a rendőrséghez tartoznak ${ }^{43}$, ugyanakkor ebben az esetben mindenképp kiemelendő, hogy a lőfegyverek esetében a rendőrség meghatározott, taxatíve felsorolt (önvédelem, munkavégzés, filmgyártás, céllövészet, oktatás, sportlövészet, személy- és vagyonvédelem, továbbá vadászat) célok vonatkozásában adhat különböző típusú engedélyeket. ${ }^{44}$ Ennek alapján tehát két hatóság rendelkezik

31 A jogalkotásról szóló 2010. évi CXXX. törvény 3. §.

32 Alaptörvény T) cikk (2) bekezdés.

33 2017. január 1. napját megelőzően a vonatkozó feladatokat a Magyar Kereskedelmi Engedélyezési Hivatal (a továbbiakban: MKEH) látta el, ugyanakkor - figyelemmel a MKEH honlapján elérhető információkra (URL2), kizárólag a hatóság elnevezése módosult, érdemi változásra nem került sor. Budapest Főváros Kormányhivatalának egyes ipari és kereskedelmi ügyekben eljáró hatóságként történő kijelöléséről, valamint a területi mérésügyi és müszaki biztonsági hatóságokról szóló 365/2016. (XI. 29.) Korm. rendelet 2 . § (2) bekezdés b) pont, (3) bekezdés.

34 156/2017. (VI. 16.) Korm. rendelet 10. § (1) bekezdés.

35 156/2017. (VI. 16.) Korm. rendelet 16. § (1) bekezdés.

36 156/2017. (VI. 16.) Korm. rendelet 17. §.

37 156/2017. (VI. 16.) Korm. rendelet 23. § (1) bekezdés.

38 156/2017. (VI. 16.) Korm. rendelet 24. § (1) bekezdés.

39 13/2011. (II. 22.) Korm. rendelet 9. § (1) bekezdés.

40 13/2011. (II. 22.) Korm. rendelet 16. § (1) bekezdés.

41 13/2011. (II. 22.) Korm. rendelet 7. § (1) bekezdés.

42 13/2011. (II. 22.) Korm. rendelet 18. § (1) bekezdés.

43 2004. évi XXIV. törvény 3. § (1) bekezdés.

44 2004. évi XXIV. törvény 2. § 43. pont. 
hatáskörrel az engedélyezési eljárások vonatkozásában, ugyanakkor a hatásköreik egyes esetekben - ideértve különösen az ML1-ben szereplő termékeket, azok közül is specifikusan a vadászatra és a sportcélra használt lőfegyvereket - átfedésben vannak és a gyakorlatban nem jelenik meg a jogszabályban sem megfelelő módon szabályozott elkülönülés.

\section{A gyakorlati megvalósulás}

A hatásköri átfedések tisztázása érdekében a Magyar Lőfegyver és Lőszerkereskedők Országos Érdekképviseleti Szövetsége (a továbbiakban: MLLKOSz), amely a magyar lőfegyver- és lőszerkereskedők szakmai érdekképviseletét látja el Magyarországon, továbbá az Európai Unió tagállamaiban, valamint egyéb hazai és nemzetközi kapcsolatokban 2018. novembere és 2020. januárja között több alkalommal is állásfoglalás iránti kérelemmel fordult egyes minisztériumokhoz, illetve szervekhez. Az állásfoglalás iránti kérelmek tárgya minden esetben három kérdés köré összpontosult: elsőként arról kértek állásfoglalást, hogy a nem kifejezetten haditechnikai (tehát vadászati vagy sportcélú) golyós fegyverek és löszerek forgalmazásához kifejezetten haditechnikai engedély is kell vagy elegendő a rendőrségi engedély. A második kérdés szerint a haditechnikai engedéllyel rendelkező vállalkozás Magyarországra behozott, haditechnikai eszközként nevesített fegyvert és lőszert - amennyiben az az ML1-ben meghatározott kivételi körbe tartozik - hogyan tudja polgári, tehát vadászati és sportcélú eszközként értékesíteni. A harmadik kérdés pedig annak tisztázására irányult, hogy a jogalkalmazói gyakorlat mennyiben áll összhangban a vonatkozó magyar és európai uniós szabályozással. ${ }^{45}$

A vonatkozó jogszabályok alapján a rendészettel kapcsolatos feladatok a belügyminiszter hatáskörébe tartoznak ${ }^{46}$, így az MLLKOSz elsőként megkereste a Belügyminisztériumot (a továbbiakban: BM) az említett kérdésekkel. A BM állásfoglalása szerint az említett jogszabályok között alá-fölérendeltségi vagy elsőbbségi viszony nem áll fenn, a normatív követelményeket párhuzamosan, egymásra való tekintet nélkül kell alkalmazni. Az állásfoglalás emellett rögzíti, hogy a Httv. hatályának deklarálása mellett a Lftv. ugyanazon tevékenységfajtákkal kapcsolatos hatósági engedélyezésre vonatkozó konkurens elöírásai nem alkalmazhatók. ${ }^{47}$

45 Az egyes állásfoglalás iránti kérelmeket az azokra adott válaszok alapján dolgozom fel és az azokban meghatározott iktatószámokat alkalmazok azonosítás érdekében.

46 A Kormány tagjainak feladat- és hatásköréről szóló 94/2018. (V. 22.) Korm. rendelet 40. § (1) bekezdés 20. pont.

47 A Belügyminisztérium BM/18631-6/2018. iktatószámú, a fegyver, valamint a haditechnikai tárgyú jogszabályok egyes rendelkezéseinek alkalmazása tárgyában kelt megkeresésre adott válasz. 
A BM javaslata alapján az MLLKOSz az Innovációs és Technológiai Minisztériumhoz (a továbbiakban: ITM), mint iparügyekért is felelös minisztériumhoz fordult ${ }^{48}$, amely során további tisztázó kérdések feltevésére is sor került. Az állásfoglalás iránti kérelemre adott válaszban az ITM rögzítette, hogy haditechnikai szolgáltatás nyújtására kizárólag haditechnikai tevékenységi engedély birtokában kerülhet sor, ugyanakkor lehetséges egyfajta átvezetés a polgári nyilvántartásba a Htr. 2. mellékletében foglaltak alkalmazásával. Az ITM álláspontja szerint a felmerült kérdések részben a BM-hez tartoznak. ${ }^{49}$ Az MLLKOSz ezt követően további értelmezési kérdésekkel fordult az ITM-hez, és állásfoglalást kért arra vonatkozóan, hogy milyen jogszabály határozza meg azokat a müszaki tulajdonságokat, amelyek alapján egyes meghatározott termékeket (például egy központi gyújtással üzemelő golyós lőfegyvert) katonai termékként kell kezelni, illetve hogyan történik a besorolás, amennyiben a termék gyártója tanúsítványban jelöli meg az adott termék célját, különös figyelemmel a vonatkozó európai uniós szabályozásra. A második állásfoglalásában az ITM (a továbbiakban: Állásfoglalás) rögzítette, hogy nincs olyan vonatkozó jogszabály, amely meghatározná a müszaki paramétereket, így azok az eszközök, amelyek a Htkr.-ben szerepelnek egyértelmüen haditechnikai terméknek minősülnek. Kiemelendő ugyanakkor, hogy az ITM álláspontja szerint a 91/477/EGK irányelv rendelkezései nem alkalmazandók a katonai termékekre vonatkozóan, amelyek egy másik európai uniós jogszabályban találhatók és amelyek teljes mértékben megegyeznek a Htkr. mellékleteiben, különösen az ML1-ben foglaltakkal. Az ITM minden, az ML1-ben szereplö termék esetén a 2009/43/EK irányelv és így a Htkr. rendelkezéseit tartja irányadónak, figyelmen kívül hagyva az egyéb jogszabályokban, így a 91/477/EGK-ban és az Lftv.-ben foglalt szabályokat. ${ }^{50}$ Megvizsgálva ugyanakkor az Állásfoglalásban foglaltakat, megállapítható, hogy az irányelvi rendelkezések átültetésére nem megfelelően került sor, tekintettel arra, hogy a 2009/43/EK irányelv vonatkozó rendelkezései lényegesen eltérnek az ML1-töl, különösen, hogy az irányelv kifejezetten rögzíti, hogy nem engedélykötelesek ${ }^{51}$ a sport és vadászati célra használt sima csövü fegyverek, ha azok nem katonai célra lettek tervezve vagy nem automata tüzelési

48 94/2018. (V. 22.) Korm. rendelet 116. § 15. pont.

49 Az Innovációs és Technológiai Minisztérium IPFO/47377-2/2018/ITM. iktatószámú, Válaszlevél a haditechnikai tevékenységet szabályozó jogszabályok értelmezéséről kért állásfoglalásra tárgyú kérelemre.

50 Az Innovációs és Technológiai Minisztérium IPFO/67659-1-2018/ITM iktatószámú, Válaszlevél a haditechnikai tevékenységet szabályozó jogszabályok értelmezéséről kért állásfoglalásra tárgyú kérelemre.

51 Az angol nyelvü változatban a „,does not control”, míg a német nyelvü változatban az ,erfasst nicht” kitétel szerepel. 
rendszerüek. ${ }^{52}$ Ezzel szemben a Htkr.-ben foglalt ML1 kimondja, hogy az ML1 huzagolatlan csövü fegyverekre vonatkozó rendelkezései nem vonatkoznak a vadászati és sport célra használt huzagolatlan csövü fegyverekre, amelyek nem lehetnek kifejezetten katonai célra tervezve vagy automata tüzelési rendszerüek. ${ }^{53}$ Mindezek felvetik annak a szükségességét - különös tekintettel az Európai Unió Bíróságának joggyakorlatára ${ }^{54}$-, hogy egyes esetekben szükség lehet a 2009/43/EK irányelv egyes részeinek szöveghü átültetésére is. ${ }^{55}$

A minisztériumok mellett az MLLKOSz állásfoglalás iránti kérelemmel fordult a haditechnikai engedélyezést végző hatósághoz, a BFKH-hoz is, azonban ezen kérelemben már némileg eltérő kérdések feltevésére került sor. Az MLLKOSz arra vonatkozóan kért tájékoztatást, hogy a nem haditechnikai, tehát sport vagy vadászati célú golyós fegyverek magyarországi forgalmazásához, illetve egyéb tevékenységekhez mindenképp hadiipari tevékenységi engedély szükséges vagy elegendő-e a rendőrségi engedély is. Emellett kérték a tájékoztatásban annak kifejtését is, hogy amennyiben egy vállalkozás haditechnikai engedéllyel rendelkezik, de nem haditechnikai termékeket hoz Magyarország területére és azokat polgári felhasználású termékként értékesíti, milyen feltételekkel teheti ezt meg. A tájékoztatáskérés harmadik része arra irányult, hogy amennyiben nem haditechnikai termékekkel foglalkozik és rendelkezik megfelelő rendőrségi engedéllyel, akkor a forgalmazás során elkövethet-e bármilyen, a Büntető Törvénykönyvben szabályozott büncselekményt. A BFKH állásfoglalása szerint a Htkr. nem emeli ki az egyes, esetenként polgári célra is alkalmas eszközöket az ML1 hatálya alól, az ott szereplő valamennyi termék alkalmasnak minősül kifejezetten katonai, nemzetbiztonsági, rendvédelmi és rendészeti célokra, függetlenül a tényleges végfelhasználástól. Emellett rögzítette, hogy az alkalmasság nem tekinthető egyenlőnek a kifejezetten katonai, nemzetbiztonsági stb. célra történő tervezettséggel, hivatkozva a funkcionális és a müszaki megközelítésre is. ${ }^{56}$ Ezt követően az MLLKOSz észrevételeket nyújtott be, hangsúlyozva, hogy egyes eszközök (például vadászfegyverek, vadászlöszerek) esetében nem szükséges a kiemelés a haditechnikai termékek közül, tekintettel arra, hogy azok nem abba a körbe tartoznak, emellett amennyiben minden esetben hadiipari engedélyre lenne szükség az ilyen termékek vásárlásához, akkor a gyakorlatban nem lenne lehetőség polgári célra fegyvereket vagy

52 2009/43/EK irányelv Melléklet ML1 1. megjegyzés.

53 156/2017. (VI. 16.) Korm. rendelet 1. melléklet 1. fejezet b) pont negyedik Megjegyzés c) pontja.

54 Lásd: C-339/87. sz. ítélet Európai Bizottság kontra Holland Királyság.

55 C-339/87. sz. ítélet Európai Bizottság kontra Holland Királyság 26. pont.

56 Budapest Főváros Kormányhivatalának BP/15-HTO-Á/671-2/2018. ügyiratszámú, Megkeresésre adott válasz tárgyú állásfoglalása. 
lőszereket vásárolni, hiszen azokhoz is hadiipari engedély megléte válna szükségessé. A BFKH erre adott állásfoglalásában fenntartotta korábbi álláspontját. ${ }^{57}$

Az MLLKOSz állásfoglalás iránti kérelemmel fordult az Országos Rendôrfőkapitánysághoz (a továbbiakban: ORFK) is, amely válaszában rögzítette, hogy a kérdések megválaszolása a BFKH hatáskörébe és illetékességébe tartozik. ${ }^{58} \mathrm{Az}$ MLLKOSz emellett megkereste a Legfőbb Ügyészséget is hasonló kérdésekkel, azonban a Legfőbb Ügyészség - hivatkozva az Alaptörvény B) cikkének (1) bekezdésében foglaltakra - megállapította hatáskörének hiányát a felmerült jogértelmezési kérdésekben. ${ }^{59} \mathrm{Az}$ összesen hét állásfoglalást megvizsgálva megállapítható, hogy az MLLKOSz az ML1 vonatkozásában egyáltalán nem kapott olyan releváns válaszokat, amelyek megfelelően indokolták és alátámasztották a felmerült kérdéseket, emellett nem került sor annak tisztázásra, hogy a Htkr.-ben szabályozott nem kifejezetten haditechnikai termékek engedélyezése hogyan és melyik hatóság által történik.

\section{Gyakorlati kitekintés: az ML1 alkalmazása az Európai Unióban}

Az eddig részletesen bemutatott jogi szabályozás mellett - ideértve a jogszabályokkal kapcsolatosan felmerült, jogértelmezésre irányuló állásfoglalásokat is - mindenképp célszerü megvizsgálni és elemezni, hogy a gyakorlatban milyen módon történik a 91/477/EGK irányelv és a 2009/43/EK irányelv európai uniós alkalmazása, hogy az egyes tagállamok hogyan értelmezik a gyakorlatban a haditechnikai termék kontra polgári felhasználású termékek kérdéskörét.

A külföldi gyakorlat a magyar-román viszonylatban került vizsgálatra, amelynek keretében egy román gazdasági társaság állásfoglalás iránti kérelmet nyújtott be az ORFK részére annak tisztázása érdekében, hogy kettős felhasználású termékek esetében hogyan alakul az engedélyezési kötelezettség. Az ORFK állásfoglalásában rögzítette, hogy amennyiben a kereskedelmi célból behozni vagy kivinni kívánt lőfegyverek, lőszerek jellemzőik alapján a Htkr. mellékletében megjelennek, azok engedélyezése a BFKH hatáskörébe és illetékességébe tartozik. Amennyiben kizárólag a Lftv. hatálya alá tartozó eszközökkel kapcsolatos tevékenységről van szó, az engedélyezés a rendőrség hatáskörébe tartozik. ${ }^{60}$

57 Budapest Főváros Kormányhivatalának BP/15-HTO-Á/671-6/2018. ügyiratszámú, Megkeresésre adott válasz tárgyú állásfoglalása.

58 Az Országos Rendőr-Főkapitányság 29000/29077-1/2018. ált. számú állásfoglalása.

59 A Legföbb Ügyészség T.KvFE.2980/2018/1-I. számú állásfoglalása.

60 Az Országos Rendőr-Főkapitányság 29000/30619-1/2018. ált. számú állásfoglalása. 
Megvizsgálva az MLLKOSz által rendelkezésre bocsátott gyártói igazolásokat ${ }^{61}$, amelyeket az MLLKOSz az egyes állásfoglalás iránti kérelmeiben az ITM részére megküldött, megállapítható, hogy az egyes gyártók nyilatkoznak, hogy az általuk gyártott és magyarországi gazdasági társaság részére értékesített löfegyverek és lőszerek, illetve egyéb eszközök kizárólag polgári felhasználásúak.

\section{Összefoglalás}

Összefoglalva a fentieket, megállapítható, hogy az ML1 tekintetében a magyar és az európai uniós jogszabályok több átfedést tartalmaznak, amelyek feloldására további egyeztetések vállhatnak szükségessé. Az átfedések egyrészt megjelennek a fogalmak körében, másrészt pedig az eljáró hatóságok hatáskörének tisztázatlanságában is. Ezen felvázolt problémák miatt a jogalkalmazás nem egységes az egyes jogszabályokban foglaltakra tekintettel. Javasolt a jogszabályokban szereplő átfedések, így különösen az Lftv.-ben és a Httv.-ben, illetve a Htkr.-ben foglaltak megfelelő alkalmazásának egységesítése olyan módon, hogy az egyes eljáró hatóságok részére egyértelmüen elkülöníthető legyen, hogy mely esetekben van szó polgári felhasználásról és mely esetekben haditechnikai célú felhasználásról. Az ellentmondások jelentős részének orvoslására az egyes jogszabályok megfelelő módosításával - ideértve adott esetben a vonatkozó európai uniós rendelkezéseket is - lehetőség nyílna a hatékony jogalkalmazásra és a jelenleg fennálló anomáliák és kollíziók rendezésére. További megoldási javaslat a felvázolt ellentmondások feloldására, hogy a bíróságok és az egyes hatóságok, így különösen Budapest Főváros Kormányhivatalának Kereskedelmi, Haditechnikai, Exportellenőrzési és Nemesfémhitelesítési Főosztálya az egyes jogszabályokat az azok preambulumában, a jogszabályok céljával összhangban értelmezzék, figyelemmel az Alaptörvény vonatkozó rendelkezéseire, amelyeknek révén lehetőség nyílna arra, hogy a sport- és vadászati célú fegyvereket, mint kettős felhasználású termékeket, tényleges céljuknak megfelelően minősítsék a hatóságok, és megfelelő eljárásrendet alakítsanak ki a kettős felhasználású termékek vonatkozásában. Ennek kezelésére javasolt a hatáskörrel

61 A gyártói igazolások az a következő gazdasági társaságoktól származnak: Ceska zborjovka a.s. (székhely: Svatopluka Cecha 1283, 68801 Uhersky Brod, Csehország; nyilvántartási szám: 46345965), Sellier \& Bellot a.s. (székhely: Lidicka 667, 25801 Vlasim, Csehország; nyilvántartási szám: 28982347); Sako Limited (székhely: 11101 Riihimäki, Finnország), RUAG Ammotec GmbH (jelenleg RUAG MRO Holding AG; székhely: Seetalstraße 175., 6032 Emmen, Svájc), Meopta - optika s.r.o. (székhely: Kabelikova 1., 75002 Prerov, Csehország; nyilvántartási szám: 47677023) és ezeket konkrét kereskedelmi ügyben állították ki. A gyártói igazolások jelen tanulmányban történő felhasználására külön meghatalmazás került kiállításra. 
rendelkező minisztérium által egy értelmezési útmutató kiadása, amely tisztázhatná a felmerült félreértéseket és lehetőséget biztosítana a megfelelő jogszabályértértelmezésre, annak révén pedig a kielégítő joggyakorlat kialakítására.

\section{Felhasznált irodalom}

Fábián L. (2015). Fegyverismereti vizsga - Felkészülési segédlet. Alpokalja Sportegyesület

\section{Alkalmazott jogszabályok}

Magyarország Alaptörvénye (2011. április 25.)

2019. évi LXXXIII. törvény az egyes törvények ipar- és kereskedelemszabályozási szempont-

ból történő, valamint jogharmonizációs célú módosításáról

2013. évi V. törvény a Polgári Törvénykönyvröl

2012. évi C. törvény a Büntető Törvénykönyvröl

2012. évi LXXXVIII. törvény a termékek piacfelügyeletéről

2009. évi LXXVI. törvény a szolgáltatási tevékenység megkezdésének és folytatásának általános szabályairól

2005. évi CIX. törvény a haditechnikai termékek gyártásának és a haditechnikai szolgáltatások nyújtásának engedélyezéséről

2005. évi CLXIV. törvény a kereskedelemröl

2004. évi XXIV. törvény a lőfegyverekröl és lőszerekről

2010. évi CXXX. törvény a jogalkotásról

1997. évi CLV. törvény a fogyasztóvédelemről

94/2018. (V. 22.) Korm. rendelet a Kormány tagjainak feladat- és hatásköréről

365/2016. (XI. 29.) Korm. rendelet Budapest Főváros Kormányhivatalának egyes ipari és kereskedelmi ügyekben eljáró hatóságként történő kijelöléséről, valamint a területi mérésügyi és müszaki biztonsági hatóságokról

156/2017. (VI. 16.) Korm. rendelet a haditechnikai tevékenység engedélyezésének és a vállalkozások tanúsításának részletes szabályairól

160/2011. (VIII. 18.) Korm. rendelet a haditechnikai eszközök és szolgáltatások kivitelének, behozatalának, transzferjének és tranzitjának engedélyezéséröl, valamint a vállalkozások tanúsításáról

13/2011. (II. 22.) Korm. rendelet a kettős felhasználású termékek külkereskedelmi forgalmának engedélyezéséről

32/2007. (III. 19.) GKM rendelet a haditechnikai termékek jelöléséről, valamint a haditechnikai termékek és szolgáltatások nyilvántartásáról

253/2004. (VIII. 31.) Korm. rendelet a fegyverekről és lőszerekről 
Az Európai Parlament és a Tanács 2009/43/EK irányelve (2009. május 6.) a védelmi vonatkozású termékek Közösségen belüli transzferére vonatkozó feltételek egyszerüsítéséről

A Tanács 428/2009/EK rendelete (2009. május 5.) a kettős felhasználású termékek kivitelére, transzferjére, brókertevékenységére és tranzitjára vonatkozó közösségi ellenőrzési rendszer kialakításáról

A Tanács 91/477/EGK irányelve (1991. június 18.) a fegyverek megszerzésének és tartásának ellenőrzéséről.

A Tanács az Európai Unió közös katonai listája a Tanács által 2017. március 6-án elfogadva (a katonai technológia és felszerelések kivitelének ellenőrzésére vonatkozó közös szabályok meghatározásáról szóló 2008/944/KKBP tanácsi közös álláspont által szabályozott eszközök).

A Bizottság jelentése az Európai Parlamentnek és a Tanácsnak: A védelmi vonatkozású termékek Közösségen belüli transzferére vonatkozó feltételek egyszerüsítéséről szóló, 2009. május 6-i 2009/43/EK európai parlamenti és tanácsi irányelv értékelése, COM (2016) 760 final.

Fővárosi Ítélőtábla Bhar.280/2018/6.

Fővárosi Ítélőtábla 4.Bf.15/2013. I.

Csongrád Megyei Bíróság B.1059/2007.30.

Fővárosi Bíróság B.255/2009.82.

C-482/17. sz. Cseh Köztársaság kontra Európai Parlament és az Európai Unió Tanácsa

C-339/87. sz. ítélet Európai Bizottság kontra Holland Királyság

A Belügyminisztérium BM/18631-6/2018. iktatószámú, a fegyver, valamint a haditechnikai tárgyú jogszabályok egyes rendelkezéseinek alkalmazása tárgyában kelt megkeresésre adott válasz.

Az Innovációs és Technológiai Minisztérium IPFO/47377-2/2018/ITM. iktatószámú, Válaszlevél a haditechnikai tevékenységet szabályozó jogszabályok értelmezéséről kért állásfoglalásra tárgyú kérelemre adott válasz.

Az Innovációs és Technológiai Minisztérium IPFO/67659-1-2018/ITM iktatószámú, Válaszlevél a haditechnikai tevékenységet szabályozó jogszabályok értelmezéséről kért állásfoglalásra tárgyú kérelemre adott válasz

A Legfőbb Ügyészség T.KvFE.2980/2018/1-I. számú állásfoglalása

Budapest Főváros Kormányhivatalának BP/15-HTO-Á/671-2/2018. ügyiratszámú, Megkeresésre adott válasz tárgyú állásfoglalása.

Az Országos Rendőr-Főkapitányság 29000/29077-1/2018. ált. számú állásfoglalása.

Az Országos Rendőr-Főkapitányság 29000/30619-1/2018. ált. számú állásfoglalása

\section{A cikkben található online hivatkozások}

URL1: 2019. évi LXXXIII. törvény indokolás az egyes törvények ipar-és kereskedelemszabályozási szempontból történö, valamint jogharmonizációs célú módositásáról szóló 2019. évi LXXXIII. törvényhez. https://mkogy.jogtar.hu/jogszabaly?docid=A1900083.TV 
URL2: Budapest Föváros Kormányhivatala. Kereskedelmi, Haditechnikai, Exportellenörzési és Nemesfémhitelesitési Föosztály. https://mkeh.gov.hu/

\section{A cikk APA szabály szerinti hivatkozása}

Minkó-Miskovics M. \& Szabó Cs. (2021). Polgári és a haditechnikai felhasználású eszközök szabályozásának hazai és nemzetközi kérdései. Belügyi Szemle, 69 (5), 817-834. https://doi. org/10.38146/BSZ.2021.5.6 